\title{
Universiteit
}

Leiden

The Netherlands

\section{Transfer of Swahili 'until' in contact with East African languages}

Mous, M.P.G.M.; Smith, N.; Veenstra, T.; Aboh, E.O.

\section{Citation}

Mous, M. P. G. M. (2020). Transfer of Swahili 'until' in contact with East African languages. In N. Smith, T. Veenstra, \& E. O. Aboh (Eds.), Contact Language Library (pp. 217-233).

Amsterdam: John Benjamins Publishing Company. doi:10.1075/coll.57.07mou

Version:

License:

Downloaded from: $\quad$ https://hdl.handle.net/1887/3243726

Publisher's Version Act/Law (Amendment Taverne)
Licensed under Article 25fa Copyright

Note: To cite this publication please use the final published version (if applicable). 


\title{
Transfer of Swahili 'until' in contact with East African languages
}

\author{
Maarten Mous \\ Leiden University
}

\begin{abstract}
Swahili has transformed the noun mpaka 'boundary, border' into a function word 'until', which has successfully spread to many other East African languages with locative and temporal readings. The grammaticalisation originated in a $\mathrm{N}-\mathrm{N}$ construction without an associative 'of' interpreted as limiting the action adverbially. The main function is in the time interpretation of 'until'. I provide an overview of this transfer in East Africa by looking at a large number of languages and argue that parallel independent grammaticalisation is not what is at stake but rather transfer of the function word and the preposition-like function.
\end{abstract}

Keywords: grammaticalisation, borrowing, East Africa, 'until'

\section{Introduction}

The Swahili word mpaka is a class 3 noun meaning 'border, boundary' and is also used as a function word meaning 'until', for both locational and temporal goals. A function word for 'until' mpaka is used in most languages of East Africa. In many of these languages we can show that mpaka (or variants thereof) is a borrowing from Swahili. The function word mpaka resembles a preposition: it is preposed to the noun with no additional material, and it links the noun to the state of affairs expressed in the verb. For the many Bantu languages in East Africa an alternative view to this borrowing scenario is conceivable, namely that of independent parallel grammaticalisation of the noun 'border, boundary' to 'until'. While this scenario cannot be ruled out for all the languages under discussion, we can show that this has not been the case for most of them. 


\section{The grammaticalisation of 'boundary' to 'until'}

In Swahili we can observe the grammaticalisation of the word for 'boundary, border', mpaka, to have developed the function of expressing 'until'. It is a clear instance of grammaticalisation. Heine and Dunham (2010) in their article on grammaticalisation in Swahili and other Bantu languages provide a framework for grammaticalization of four parameters: (i) extension; (ii) desemanticization; (iii) decategorialization; (iv) erosion. I discuss these parameters one by one.

Parameter (i) extension: Mpaka 'boundary' has extended by pragmatic use in not only referring to the physical entity of a boundary but also using the concept of boundary as a limit for the state of affairs expressed in the verb. When a noun phrase "boundary X" is interpreted as functioning as an adverbial phrase the interpretation is that the boundary is the limit of the state-of-affairs expressed in the verb and hence translatable with 'until', see Krifka (1983: 125). In (1b) the constituent with boundary is interpreted as an adjunct. With that extension in pragmatic use, the interpretation of 'boundary' extends or shifts to 'until'.
(1) a. I see [the boundary of $\mathrm{X}]$
b. I walk [the boundary X] = 'I walk until X'
c. I walk [the boundary tomorrow] = 'I walk until tomorrow'

Once the constituent with mpaka is interpreted as an adverbial phrase it is very easy to use a temporal noun in the position of X replacing a locative noun. But in that case mpaka no longer refers to the boundary of the temporal noun; boundary is no longer conceptualised as referring to $\mathrm{X}$ but as only limiting the state of affairs expressed in the verb; rather than the boundary of tomorrow, the concept of boundary of walking is evoked: "I walk until tomorrow".

The crucial drive behind the extension is the interpretation of a noun phrase as an adverbial phrase. This in itself is very common in Swahili syntax (Krifka 1985: 125).

Parameter (ii) of desemanticization goes hand in hand with the extension sketched above. The semantic development is that the physical boundary becomes a limit to the action as a corollary of the constituent functioning as adverbial phrase. Limiting the action of the verb has as a consequence that a time interpretation comes to the foreground. As soon as what follows mpaka is an indication of time, this moment in time can be expressed just as easily in a clause as in a noun.

Parameter (iii) of decategorialization is again a consequence of the word mpaka now referring to the limit of an action and hence all properties of decategorialization of nouns that Heine and Durham mention apply to mpaka which loses "morphological distinctions of number, gender, case, etc., the ability to combine with adjective, determiners, etc., to be headed by adpositions,..." (Heine \& Durham 2010: 34). 
Parameter (iv) of erosion is possibly also at stake in the reduction of the initial nasal of mpaka from a syllabic nasal to pre-nasalisation. However, I am not certain about the facts here. On the one hand, such an erosion is reported in the recent dictionary Kamusi kuu ya Kiswahili (Baraza la Kiswahili 2015) which indicates this distinction with a different placement of the stress mark: mipaka 'boundary' versus 'mpaka 'until'. The syllabic nasal of the noun mpaka 'boundary' is the nominal class prefix of class 3 . The initial nasal of the functional word 'until' is invariable and in the absence of any agreement to the function word 'until' there is little incentive to consider its initial nasal element as a separate morpheme and reduction to prenasalisation is favoured. However, I am not entirely sure that the reduction to prenasalisation is a linguistic fact. Swahili poets such as Farouk Topan, whom I consulted during the Swahili colloquium in Bayreuth in 2016 did not perceive any rhythmic difference between the two forms and conceived the form for 'until' as containing three syllables.

A final factor that needs to be discussed is the absence of an associative in the mpaka X construction. Swahili Noun + Noun constructions usually contain an associative, mpaka wa $X$, with wa referring to class 3 of mpaka. This issue is dealt with in Section 3.

Grammaticalisation from 'boundary' to 'until' seems perfectly logical but is in fact not very common. The lexicon of grammaticalization (Heine \& Kuteva 2002: 61) mentions only Swahili and Mooré. I am not convinced, however, that the Moore example shows grammaticalization to 'until'. The most extensive dictionary of Mooré, Nikiema and Kinda (1997: 921), does indeed suggest grammaticalisation of the word for boundary as it gives for tcka 'fin, limite' as well as à partir de, depuis' but the conceptual extension is rather different, developing into a point of departure rather than a telic goal.

But the same grammaticalisation happened in Arabic as I learned from my colleague Ahmad Al-Jallad. In Arabic hattā 'until' has undergone similar grammaticalisation from the noun hadd 'boundary' followed by a relative marker yielding haddī-tā /border-which/ (this form exists in the Levantine dialects). The further developments in form are $>$ haddta $\bar{c}$ hatta ${ }^{1}{ }^{1}$ The same simplification of $d d t$ happened in the parallel grammaticalisation of the conjunction hadd-tay $>$ hattay 'until' with tay being a subordinating element (Al-Jallad 2017).

Next to the grammaticalisation of 'boundary' to 'until' Swahili has borrowed hata or hati from Arabic for 'until'. Thus, it may seem that the grammaticalisation of mpaka in Swahili is modelled on Arabic. However, that would require to assume quite intimate knowledge and analysis of Arabic on the part of the speakers that

1. In Arabic the conjunction can also express purpose, concession. 
recognised the model at the time of grammaticalisation. Moreover, the grammaticalisation in Arabic including the devoicing of $d d$ occurred in pre-Quranic times and hence long before the first contact of Arabic with Swahili. Therefore, I conclude that the Swahili grammaticalisation is not modelled on the Arabic one. The conceptual shift from 'boundary' to 'until' is the same in Arabic and in Swahili but also very straightforward. The developments in form are quite different. While the Arabic preposition and conjunction contain second elements expressing the relation, the Swahili preposition crucially does not include the relating associative. Swahili (or Bantu) internally such an inclusion of an associative in the preceding element is indeed not to be expected because an intonational brake in such a construction in a Bantu language would fall before the associative and certainly not after it and hence an associative would not merge with the preceding word for 'boundary' or 'until'.

\section{The construction with mpaka 'until' in Swahili}

The Swahili dictionaries recognise the preposition-like usage of the word mpaka for 'boundary'. Sacleux (1939) has 'jusque' with locative and time complements. Johnson (1939) derives mpaka 'boundary' from the verb paka 'make a boundary' and gives for the prepositional usage the following equivalents: 'up to, to, as far as, till, until, to the time of', and gives the words hata, hadi as comparable to mpaka and as preposition borrowed from Arabic. ${ }^{2}$ TUKI (2001) has two entries for mpaka; one as the noun for 'border' and one as a preposition 'until, to, up to'. TUKI (1981), a Swahili-Swahili dictionary, gives the Swahili equivalents hadi and hata.

In order to understand the transfer process, we should have a closer look at the meaning, functions and uses of mpaka in Swahili. To this end I consulted the Helsinki Swahili Corpus (HSC 2.0). The corpus contains 15,093 instances of mpaka (a comparable word such as katika 'in' has 281,094 instances). A first cursory investigation taking the first 100 instances of mpaka in the Helsinki Swahili corpus shows 54 instances with a sentential complement indicating a moment in time, 27 with a nominal complement indicating a point in time, and only 17 that have a locative complement and these are all nominal in nature, 2 instances that are used in "counting" (e.g. tano mpaka nane 'five to eight'), and only 1 instance of 'border' was noted. The percentages are displayed in the following pie diagram. This shows an overwhelming majority of use with time complements and of use as clause introducer. ${ }^{3}$

2. Presently hata $X$ is used as emphasizer 'even $X$ ' rather than for 'until'. Johnson (1939) also mentions upeo 'limit' used adverbially as intensifier of the verb rather than preposed to a noun, from the verb pea 'become fully grown'

3. I have counted infinitival complements, which are grammatically nominal, as clausal since they too require the interpretation of an event as a moment in time. 


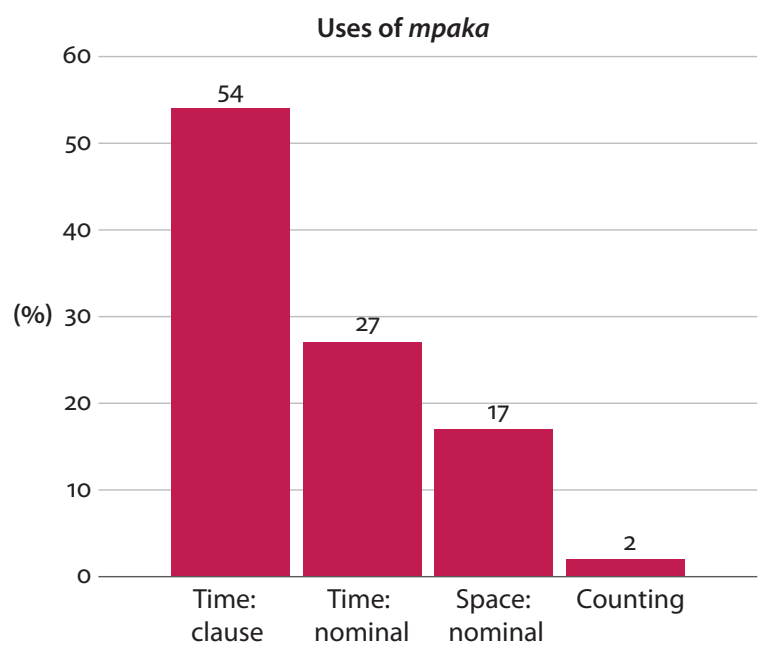

Very common collocations with mpaka in the corpus are mpaka sasa 'till now' (1906 of 15093 or $12.6 \%$ of the instances of mpaka), others are mpaka leo 'till today' (850), mpaka kesho 'till tomorrow' (136), and mpaka mwisho 'till the end' (165). The use of mpaka as 'border, boundary' is far from obsolete. The Helsinki corpus contains at least some 3500 instances. ${ }^{4}$

Perusing the Helsinki corpus, I came across only two instances of mpaka used in the meaning of 'until' but followed by an associative marker (see discussion below why mpaka is not followed by an associative). Both instances came from the part of the corpus that is based on novels and not from the news and parliamentary proceedings. I consider these uses to be prescriptive attempts. Both examples come from materials for a university course in literature in Dar es Salaam's Swahili department where correct Swahili is moulded.

(2) Mpango huu, u-na-o-patikana Mombasa mpaka wa leo 3.plan 3:this 3-PREs-3.REL-available Mombasa until 3:of today huko u-na-itwa ku-funga nyama

3:this.one 3-PRES-call:PAS 15-close meat

'This plan, which is available in Mombasa, until today this is called "to close meat"

(from HSC 2.0: Makala za Semina ya Kimataifa ya Waandishi wa Kiswahili III Fasihi. Dar es Salaam: Taasisi ya Uchunguzi wa Kiswahili cha Chuo Kikuu, 1983)

4. Obviously this is not easy to count such instances by looking for form only but I counted instances of mpaka plus associative 'of' (394), the plural form, mipaka (1971), and the locative forms mpakani 'at the border' (748), and its plural mipakani (338). 
(3) Maelezo haya ya-me-vuka mpaka wa ku-ona ki-tu 6.explanation 6:these 6-PRF-cross until 3:of 15-see 7-thing kama ki-livyo

like 7 -it.is

'These explanations extended until seeing something as it is.'

(from HSC 2.0: Makala za Semina ya Kimataifa ya

Waandishi wa Kiswahili III Fasihi Dar es Salaam: Taasisi ya Uchunguzi wa Kiswahili cha Chuo Kikuu, 1983)

In short, the use of mpaka for 'until' in Swahili may indicate a location as endpoint of a path with focus on that end point, or it may indicate a goal. A goal is often expressed without the addition of mpaka; for example, rudi nyumbani 'return home'. In examples of locational use of mpaka 'until', the occurrence of a path is common, but expressing a goal with mpaka without a path is not impossible.

By far the most common use of mpaka 'until' is for time. Mpaka indicates a time period with an endpoint and focus on that endpoint. Mpaka is also used in series of comparable entities (such as counting) with focus on their endpoint. Time is the major function of mpaka in actual language use. It offers the speaker an option to express a period of time as adjunct and hence also easily functions as a clause introducer.

The construction with mpaka 'until' is different from other prenominal nouns that have developed into function words in Swahili that contain the associative like mbele ya 'in front of', kati ya 'in the middle of', juu ya 'on top of', ndani ya 'inside of', nyuma ya 'behind of'. The mpaka 'until' construction fits better in a set of other constructions with a preplaced noun and no associative such as hadi $N$ 'until N', tangu $N$ 'since N', toka $N$ 'from N', katika $N$ 'in N', kama $N$ 'like N', bila $N$ 'without $\mathrm{N}$ ', kuliko $N$ 'than N', kila $N$ 'every N', hata $N$ 'even N' (see Kapinga 1983). What these structures have in common is that they lack an associative and are often translated using prepositions but the set is not at all homogeneous; some of the initial elements are borrowed from Arabic (hadi, hata, bila, kila) other are not; some are verbal in origin (toka from $k u$-toka 'to come from') or originate in a construction ( $k u$-li-ko 17-be-17:REL). The relevance of this list for understanding mpaka $X$ is that there are models in the language for this construction. ${ }^{5}$

Next to the $\mathrm{N}$ associative $\mathrm{N}$ construction Swahili also has $\mathrm{N} \mathrm{N}$ constructions where the second noun is not a modifier of the first noun but rather an equivalent of the first noun. This is the case in a construction like $n d u g u X$ 'brother/friend X' which is used in addressing people: $\mathrm{X}=$ brother, the meaning is not 'brother of $\mathrm{X}^{\prime}{ }^{6}$ The conceptual frame is not one of modification and this is also the case in the

5. However, Makhuwa may use the associative in the function of 'until', in mpákhá wa-ámútsy' ááwe 'to his family's place' (van der Wal 2009: 48, example 129).

6. The structure resembles Swahili compounds such as nya+X 'mother=X' as in Nyamwezi. 
mpaka X construction: mpaka sasa 'until now' does not develop from 'border of now' but from 'border is now'. The expression of time is semantically not a modification of the boundary and, therefore, the structure is not one with the associative marker. When mpaka is followed by a time expression, the time expression is a point on time and not a period of time. For example, mpaka saa kumi means 'until 4 o'clock' and cannot refer to the boundary of ten hours. Likewise, with locative complements the semantics evoked are boundary $=\mathrm{X}$ and not boundary of $\mathrm{X}$; for example, mpaka nyumbani 'until home' does not refer of the limits of home but considers home as a limit. ${ }^{7}$

I propose that the origin of the until-construction is a $\mathrm{N}+\mathrm{N}$ construction and not the $\mathrm{N}$ associative $\mathrm{N}$ construction on the basis of its semantics. ${ }^{8}$ It has to be noted though that $\mathrm{N}$ associative $\mathrm{N}$ constructions can drop their associative. Examples are maji moto /water fire/ 'hot water' where moto does modify maji and the origin maji ya moto exists too; likewise, gari moshi /vehicle smoke/ 'train' as alternative to gari la moshi. ${ }^{9}$

When 'until' is followed by an expression indicating a moment in time the constituent with 'until' refers to the whole period from now (or another starting point) till the moment expressed after 'until' with emphasis on that endpoint. It cannot refer to only the end point. An example is 'You didn't bother until today, why do you tell me now?' (Ström 2013: 270, 1.583).

When the complement is a location, two interpretations are possible. One is comparable to the period of time and refers to the path from here (or another point) to the location expressed after 'until', as in Example (4):
(4)
Makuyuni i-po $k t k \quad$ njia i-toka-yo
M. 9-16.rel middle 9.road 9-come.fron
Arusha ku-elekea
Babati mpaka Dodoma
B until D.
'Makuyuni is on the road halfway from Arusha direction of Babati until Dodoma.' ${ }^{10}$

7. There is a third option with the general preposition na 'and, with' instead of the associative, mpaka na X. This construction is almost exclusively attested in the meaning of 'boundary' in the HSCorpus, after the English model 'boundary with'.

8. In Kagulu, locational nouns such as 'near' and 'inside' equally need no associative (Petzell 2008: 59-60).

9. I thank one of the reviewers for pointing this out to me.

10. From <http://tembeatz.blogspot.nl/2010/08/njia-panda-ya-makuyuni-mpaka-mto-wa-mbu. html $>$ (8 December 2016). 
With locational complement of mpaka reference can either be made to the whole path as in (4) or only to the endpoint as in (5). ${ }^{11}$ The same is true for languages borrowing 'until' from Swahili.

(5) ni-ka-m-geuza farasi wangu ni-ka-anza ku-rudi kwa haraka 1SG-CSEC-O1-change horse 1:mine 1sG-CSEC-start 15-return with hurry mpaka nyumbani until home

'and I changed horses and started to return home in a hurry'.

(from HSC 2.0 Salim A. Kibao 1975. Matatu ya Thamani Nairobi:

Heinemann Educational Books)

This expression of path can also be found in languages borrowing mpaka from Swahili. In Konso, we find 'Sweep this house up to the gate! (Orkaydo 2013: 181). In Mbugu we have an example expressing locational path kulí kinhko mpaká magamba ni muda wa madamo mahai to '(the distance) from Kinko until Magamba is a period of four hours only' (Mous 2003: 197). In this last example there is no movement involved; expression of path is more common with movement as in the Rangi example 'S/he is fat, s/he will not be able to go to Kondoa by foot' (Gibson 2013: 83). For time we often need to refer to periods but for location, reference for path may be relatively less common. There are plenty examples where only goal is indicated using 'until' and no path is intended as in Ndenggeleko Ywaa nkơlongwa kaabóya mpaka ukááya 'That/The man returned home' (Ström 2013: 178 example 302).

\section{Borrowing mpaka in East Africa}

The function word mpaka 'until' is remarkably often borrowed into the languages of East Africa. Most languages in East Africa use a word like mpaka for 'until'. In the Table in the Appendix I present the results of searching for mpaka 'until' in East Africa for more than 30 languages. Some non-Bantu languages borrow mpaka from Swahili. For the non-Bantu languages without mpaka I included information in the

11. The combination mpaka nyumbani is rare though in the Swahili corpus and occurs only 29 times. A few times mpaka nyumbani occurs with the verb sindikiza 'to accompany a guest for a while upon departure' in which it probably expresses the unexpectedness of the endpoint. This may also be the reason to choose mpaka nyumbani with the verb rudi 'to return, go back' over simply nyumbani. Simply nyumbani is far more common as complement of the verb rudi; over 750 instances can be found of nyumbani with rudi against only two instances of mpaka nyumbani in HSC 2.0. In the example above mpaka may have been used to express the unexpectedness too, 'all the way home'. 
table about how they express 'until'. I found some 18 Bantu languages where there is no evidence for borrowing of 'until' from Swahili. ${ }^{12}$

The grammaticalisation of 'boundary' to 'until' in Swahili has a parallel in Arabic with differences in the detail, as mentioned above; this parallel was considered to be coincidental and not due to historical influence. Swahili may not have copied this model from Arabic, but did the other languages in East Africa copy the model from Swahili and followed the same path of grammaticalisation and developed 'until' from the noun for 'boundary'? Most people in East Africa are speakers of other languages but know Swahili well enough to be able to connect the noun and the function word in Swahili. It is thus perfectly imaginable that the East African Bantu languages derived the function word from their own reflex of the word for 'boundary' following the Swahili model. Yet I will argue that for many East African Bantu languages it can be shown that they did not. Rather they borrowed mpaka from Swahili in the function of 'until'.

A number of non-Bantu East African languages have borrowed the Swahili preposition mpaka for 'until'. These are at least Ik (Kuliak, Uganda), Borana (Cushitic, Kenya, Ethiopis), Konso (Cushitic, Ethiopia) and Sandawe (KhoiSan, Tanzania). The word is often adjusted to the phonotactics of the receiving language that does not like nasal-oral stop compounds. It is obvious that in these cases only the function word mpaka is borrowed because these languages have completely different words for the concept of 'boundary'. For some of these languages there is a competing word expressing 'until'. Konso is an interesting case since Swahili is not strong in South Ethiopia and the most likely scenario is that Konso borrowed it from Borana that borrowed it in turn from Swahili; the pronunciation of Konso haka is actually identical to Borana haga despite the difference in spelling because intervocalic stops are voiced in Konso (Orkaydo 2013: 39-40).

There is no indication of such borrowing in some other East African non-Bantu languages such as Iraqw (Cushitic, Tanzania), Rendille (Cushitic, Kenya), Maasai (Niloitc, Kenya, Tanzania), Turkana (Nilotic, Kenya). We cannot rule out the possibility that these languages actually do use mpaka. In some grammars and dictionaries there is no mention of mpaka but one does frequently encounter instances of mpaka 'until' in texts. These cases are apparently considered instances of code-switching, or such a grammar writer has a purist stance favouring inherited function words above borrowed ones.

12. Makonde (Leach 2010), Kiitharaka (Muriungi 2009), Luluyia (Marlo 2007), Yao (Ngunga 2000), Rutara (Muzale 1989), Bukusu (Mutonyi 2000), Jita (Kagaya 2005), Digo (Nicolle (hata 'until' and mpaka 'boundary'), ChiNgoni (Ngonyani 2003), Lingala (Edema 1994 kíná conj), Gogo (Rugemalira 2009 Instead Gogo uses sunga + S) ${ }^{13}$, Ha (Harjula 2004), Pangwa (Stirnimann 1983), Rimi (Olson 1964), Nyiha (Busse 1960), Mwera (Harries 1950), Daiso (Nurse 2000), Kuria (Cammenga 2004). 
It is equally clear that a number of Bantu languages borrowed mpaka as 'until' because their word for 'border' is completely different: Nyamwezi, Kivunjo Chaga, Luganda, Matengo, Ekoti, Haya, see the table in the Appendix for details. For example, Luganda has borrowed paka for 'until' from Swahili while it has several different words for 'boundary': èsalè, èmbobò, ènkingì.

And in some other Bantu languages the word for 'until' resembles mpaka while the word for 'boundary' is a clearly different even if it is a reflex of the same root: Mbugwe, Rangi, Pare, Mbugu, Ndamba, Zigula, Shambala, Gweno. For example, Ndamba has mupaka 'boundary, border', but mbaka 'until'. In this instance the Swahili loan is adapted to the phonological system of the receiving language while it remains different from the regular reflex of the Bantu noun root for 'boundary'. In some other languages the loan is not adapted at all. For example, Mbugu mpaka 'until' shows the prenasalised voiceless stop which is not otherwise attested in Mbugu because such prenasalisations need to be voiceless in the language as in mhpaka 'boundary'. These languages borrowed the Swahili preposition 'until'.

There is another category of languages for which we have a strong indication that the word for 'until' is borrowed from Swahili in the similarity in form but we cannot contrast it to the word for 'boundary' due to lack of information: Ndengeleko mpaka 'until', Makonde mpááka 'until'.

For some languages we cannot rule out a parallel grammaticalisation scenario; these languages are presented in the last part of the table in the Appendix. This is particularly the case if the word for 'until' is not identical to the Swahili form. For example, Ilwana has a form for 'until' that is slightly different from Swahili namely mupaka. Nurse (2000: 210) indicates that the preposition is borrowed from Swahili; mupaka being an automatic adaptation of Swahili $m p$ to Ilwana phonology which does indeed render all syllabic nasals of Swahili loans as $m u$ (while Swahili prenasalised stops are maintained as such, see Nurse 2000: 115). Thus, a scenario that Ilwana borrowed the function word from Swahili is indeed likely. However, their word for 'boundary' is identical and presumably also borrowed from Swahili. Hence, we cannot be sure whether both are borrowed in parallel or whether Ilwana has developed a parallel grammaticalisation of noun 'border' to functional element 'until'. In Matengo both 'until' and 'boundary' are mpaka though the word for 'boundary' is indicated as having a syllabic nasal and the word for 'until' is not, but I cannot be sure that there is truly such a difference. Such a difference in syllabicity is also reported for Pare or Chasu: it has mháka for 'until' and mháka with a syllabic nasal for 'boundary'. It is possible that mhaka is the automatic adjustment in Pare for prenasalised voiceless stops that the language does not allow. But the closely related Mbugu breaks that restriction when it borrows mpaka from Swahili, next to the inherited noun mhpaka with a voiceless nasal for 'boundary'. Thus, the borrowing scenario requires automatic phonological adjustment of the loan while the parallel grammaticalisation scenario requires a reduction in form from a voiceless nasal 
stop compound to voiced nasal plus $h$. I consider this latter reduction less likely because the existing variation in closely related Mbugu is between a voiceless nasal plus voiceless stop compound $[\mathrm{mp}]$ and just a voiceless nasal without the stop part $[\mathrm{m}]$; and there is no indication of variation between (aspirated) $p$ and $h$, and the nasal in this context in inherited words is always voiceless. Hence, here too I would opt for the borrowing scenario. In sum, there is no strong evidence that parallel grammaticalisation of 'boundary' along the Swahili model is what is at stake in any of the East African languages.

The word mpaka for 'until' has spread from Swahili to many languages of East Africa in this function. Its use in Swahili and the recipient East African languages goes in tandem in a situation of extensive bilingualism. The main use is expressing a temporal period by indicating an end point. The construction mpaka + Noun or Clause is grammaticalised in Swahili from a conceptual frame 'boundary' = X. The general construction is not common in the East African languages but in this instance of mpaka it is part of Swahili grammar and copied as such in the grammars of the recipient languages.

A conceivable reason for the easy transfer of mpaka is that bilingual speakers appreciate the efficiency of a constituent with an initial element expressing an endpoint and feel the need for that in their other language(s). The attraction of a preposition-like mpaka is the fact that the relationship is expressed in a separate word dedicated to that relationship. This has advantages over an alternative in which this needs to be inferred from other relators with wider functions or from a state of affairs indicating duration and expressed in the verb in combination with a noun phrase interpreted but not marked as endpoint. This explains for example why some languages do not borrow mpaka. Some of those East African languages express the notion of 'until' with a comparable preposition-like element with a wider application. Iraqw, a Southern Cushitic language in Northern Tanzania uses the general preposition ay 'to' in ay hamti 'till now', ay dír deelodá' /to place:of day:that/ 'until that day' but also ay dir + relative clause expressing point in time for 'until'. When asked in elicitation speakers give afiqoomár /mouth:period:of/ as equivalent of 'until.' ${ }^{13}$

In a similar vein, it could be raised as an argument why Maasai does not use mpaka. Maasai has a proclitic to a time adverbial or a subordinate clause that is used "to indicate that the main clause event continues until the time or situation indicated by the time adverbial of subjunctive clause event." (Payne \& Ole-Kotikash 2008: lemma 2$).{ }^{14}$

13. Mpaka is also used occasionally in elicitation but it is not used in texts

14. Mol (1996: 254) mentions for Maasai the use of verbs in subjunctive 'to reach' and 'to be big' to express 'until'. 
The argument of experienced efficiency as incentive for the transfer can however not explain why mpaka would be borrowed by those languages that have a comparable competitor for mpaka. In some cases, the Swahili loan is clearly replacing a similar item with seemingly identical function. For example, in Ik páka and gone seem interchangeable. In Rangi the Swahili replacement is considered to be equivalent to the Rangi original but the Swahili form is simply more often used (Stegen 2011: 191). Shambala has two competing elements shuti and mpàká. ${ }^{15}$ Mpaka is used with clause complements referring to a moment in time in the examples that LangHeinrich supplies and he provides 'till that [bis dass]' as translation equivalent but he indicates that it can also be followed by locative pronouns while shuti has the same kind of complements. Shuti has a homonym in his dictionary that means 'it must be that' and this is followed by a dependent verb form while it is invariant itself (like Swahili lazima). Roehl (1911: 103) reports only this latter function for shuti and already in 1911 gives the Swahili loan mpàká for 'till that.... If shuti in the meaning of 'until' has developed from the function 'it must be that' then both competitors for 'until' are lexical innovations, one internal and one borrowed. If languages that have a similar element to mpaka to express 'until' preceding a noun or a clause, and indicating a moment in time or place, then the motivation for borrowing from Swahili cannot be the efficiency that a bilingual speaker discovered in Swahili in preposition/conjunction-like element for 'until'. It would simply reflect the dominance of Swahili.

Other East African languages have different grammatical means that have a wider application and are used for 'until'. Sandawe uses the additive suffix $k i$ in swê-nà-kí /now-to-additive/ 'until now' (Eaton 2010: 34) or it uses durative aspect in the verbal complex together with a time indicating constituent and 'until' is part of interpretation, e.g. 'I keep waiting [until] the millet sprouts' (Eaton 2010: 72 example 78).

The general pattern is that languages of East Africa borrow the preposition mpaka 'until' and do not copy the Swahili grammaticalization. In most of these speech communities Swahili is a strong second language and most speakers are bilingual in Swahili. For some languages the function word is an additive rather than a replacive borrowing. For four languages in our files there is a competing preposed functional element meaning 'until' (Ik, Makua, Rangi, Shambala). The languages that use mpaka like a preposition often include time in the contexts of use. The data is not always rich enough to establish this but it looks as if time is part of the meaning of mpaka from the start. It is probable that it is precisely in time expressions that speakers copy Swahili patterns into the other language that they

15. Which is a transfer from Swahili since the regular reflex for 'boundary' is mhaka (LangHeinrich 1921: 269, 320) 
speak. The use of a preposition 'until' has the advantage that a time period and its endpoint can be expressed in one constituent, for example pàkâ ?à tà?té until they died' (Sandawe, Eaton 2010: 103). Speakers will use mpaka in the same functions in which they can use in Swahili and hence we can find mpaka with clausal complements. Mpaka is also used to indicate the end of an enumeration (X,Y up to Z) in Mbugu and possibly other languages too, as it is in Swahili.

\section{Acknowledgements}

I would like to thank the audience of Bayreuther Swahili colloquium of 2016 and two anonymous reviewers for their extremely useful comments and suggestions.

\section{References}

Al-Jallad, A. 2017. The etymology of hattā. In To the Madbar and Back Again, Studies in the Languages, Archaeology, and Cultures of Arabia Dedicated to Michael C.A. Macdonald [Studies in Semitic Languages and Linguistics 92], L. Nehmé \& A. Al-Jallad (eds), 338-345. Leiden: Brill.

Alnet, A. 2009. The Clause Structure of the Shimaore Dialect of Comorian (Bantu). PhD dissertation, University of Illinois at Urbana-Champaign.

Baraza la Kiswahili la Taifa (Kenya). 2015. Kamusi kuu ya Kiswahili. Nairobi: Longhorn.

Besha, R. M. 1993. A Classified Vocabulary of the Shambala Language with Outline Grammar. Tokyo: ILCAA.

Busse, J. 1960. Die Sprache der Nyiha in Ostafrika [Deutsche Akademie der Wissenschaften zu Berlin. Institut für Orientforschung, Veröffentlichung 41]. Berlin: Akademie Verlag.

Cammenga, J. 2004. Igikuria Phonology and Morphology: A Bantu Language of South-West Kenya and North-West Tanzania. Cologne: Rüdiger Köppe.

Devos, M. 2008. A Grammar of Makwe (Palma; Mozambique). Munich: Lincom.

Dimmendaal, G. 1983. The Turkana Language. Dordrecht: Foris.

Dunham, M. 2005. Éléments de description du langi: Langue bantu F 33 de Tanzanie: Phonologie - grammaire - lexique. Leuven: Peeters.

Eaton, H. 2010. A Sandawe Grammar. SIL. <http://www-01.sil.org/silepubs/Pubs/52718/52718_ EatonH_Sandawe_Grammar.pdf> (12 October 2016).

Edelsten, P. \& Lijongwa, C. 2010. A Grammatical Sketch of Chindamba, A Bantu Language (G52) of Tanzania [East African Languages and Dialects 21]. Cologne: Rüdiger Köppe.

Edema Atibakwa Baboya. 1994. Dictionnaire bangála-français-lingála = Bagó na mənəkっ na bangála-frasé-lingála: Suivi d'un lexique lingála-bangála-français et d'un index français-bangála-lingála. Paris: ACCT.

Gibson, H. 2013. Auxiliary Placement in Rangi: A Dynamic Syntax Perspective. PhD dissertation, University of London, SOAS.

Harjula, L. 2004. The Ha Language of Tanzania: Grammar, Texts and Vocabulary. Cologne: Rüdiger Köppe.

Harries, L. P. 1950. A Grammar of Mwera. Johannesburg: Witwatersrand University Press. 
Heine, B., Güldeman, T., Kilian-Hatz, C., Lessau, D. A., Roberg, H., Schladt, M. \& Stolz, T. 1993. Conceptual shift: A lexicon of grammaticalization processes in African languages. Afrikanistische Arbeitspapiere 34-35. Cologne: Institut für Afrikanistik.

Heine, B. \& Kuteva, T. 2002. World Lexicon of Grammaticalization. Cambridge: CUP.

Heine, B. \& Dunham, M. 2010. Grammaticalization in Bantu with special reference to Swahili. In Bantu Languages, Analyses, Description and Theory, K. Legère \& C. Thornell (eds), 31-45. Cologne: Rüdiger Köppe.

Hendle, J. 1907. Die Sprache der Wapogoro (Deutsch-Ostafrika) nebst einem deutsch-chipogoro und chipogoro-deutschen Wörterbuche [Archiv für das Studium deutscher Kolonialsprachen 6]. Berlin.

HSC 2.0 = Helsinki Swahili Corpus 2.0, curated by Arvi Hurskainen. 2016. <http://metashare. csc.fi/repository/browse/helsinki-corpus-of-swahili-20-hcs-20/d544fe38184411e291cf005056be118e78589842c66b4efda6ad46f4034679c9/> (27 April 2020).

Johnson, F. 1939. A Standard English-Swahili Dictionary. Oxford: OUP.

Kagaya, R. 1989. A Classified Vocabulary of the Pare Language. Tokyo: ILCAA.

Kagaya, R. 2005. Jita Vocabulary. Tokyo: ILCAA.

Kagaya, R. 2006. A Kiwos̉o Vocabulary. Tokyo: ILCAA.

Kapinga, M. C. 1983. Sarufi maumbo ya Kiswahili sanifu. Dar-es-Salaam: TUKI.

Kaji, S. 2000. A Haya Vocabulary. Tokyo: ILCAA.

Kisbey, W. H. 1906. Zigula-English Dictionary. London: Society for the Promotion of Christian Knowledge.

Kossmann, M. 2005. Berber Loanwords in Hausa. Cologne: Rüdiger Köppe.

Krifka, M. 1983. Zur semantischen und pragmatischen Motivation syntaktischer Regularitäten: Eine Studie zur Wortstellung und Wortstellungsveränderung im Swahili. [Studien zur Theoretischen Linguistik 5]. Paderborn: Wilhelm Fink.

LangHeinrich, F. 1921. Schambala-Wörterbuch [Abhandlungen des Hamburgischen Kolonialinstituts, Reihe B., Völkerkunde, Kulturgeschichte und Sprachen 23]. Hamburg: Friederichsen.

Leach, M. B. 2010. Things Hold Together Foundations for a Systemic Treatment of Verbal and Nominal Tone in Plateau Shimakonde. Utrecht: LOT.

Maganga, C. \& Schadeberg, T. C. 1992. Kinyamwezi: Grammar, Texts, Vocabulary. Cologne: Rüdiger Köppe.

Marlo, M. R. 2007. The Verbal Tonology of Lunyala and Lumarachi: Two Dialects of Luluyia (Bantu, J.30, Kenya). PhD dissertation, University of Michigan, Ann Arbor.

Mol, F. 1996. Maasai Language \& Culture Dictionary. Lemek, Kenya: Maasai Centre.

Morrison, M. 2011. A Reference Grammar of Bena. PhD dissertation, Rice University. <https:// scholarship.rice.edu/handle/1911/70359> (27 April 2020).

Mous, M. 1993. A Grammar of Iraqw. Hamburg: Helmut Buske.

Mulira, E. M. K. \& Ndawula, E. G. M. 1952. A Luganda-English and English-Luganda Dictionary. London: Society for Promoting Christian Knowledge.

Muriungi, P. 2009. Phrasal Movement inside Bantu Verbs: Deriving Affix Scope and Order in Kîitharaka. PhD dissertation, CASTL Universtiy of Tromsø. <https://munin.uit.no/bitstream/handle/10037/1720/thesis.pdf?sequence=1> (27 April 2020).

Murphy, J. D. \& Kiggundu, C. 1972. Luganda-English Dictionary. Washington DC: Consortium Press for Catholic University of America Press.

Mutonyi, N. 2000. Aspects of Bukusu Morphology and Phonology. PhD dissertation, Ohio State University.

Muzale, H. 1989. A Reconstruction of the Proto-Rutara Tense/Aspect System. PhD Memorial University of Newfoundland, St. John's. 
Ngonyani, D. 2003. A Grammar of Chingoni. Munich: Lincom.

Ngunga, A. 2000. Phonology and Morphology of the Ciyao Verb. Stanford CA: CSLI.

Nicolle, S. 2013. A Grammar of Digo: A Bantu Language of Kenya and Tanzania. Dallas TX: SIL.

Nikiema, N. \& Kinda, J. 1997. Dictionnaire orthographique du moore. Ouagadougou: Sous-commission Nationale du Moore.

Nurse, D. 2000. Inheritance, Contact, and Change in Two East African Languages. Cologne: Rüdiger Köppe.

Olson, H. S. 1964. The Phonology and Morphology of Rịmi. PhD dissertation, University of Hartford, Connecticut.

Orkaydo, O. O. 2013. A Grammar of Konso. Utrecht: LOT.

Payne, D. L. \& Ole-Kotikash, L. 2008. Maa Dictionary, Maasai (IlKeekonyokie, IlPurko, IlWuasinkishu) and Samburu. <http://darkwing.uoregon.edu/ maasai/> (12 October 2016).

Petzell, M. 2008. The Kagulu Language of Tanzania: Grammar, Texts and Vocabulary. Cologne: Rüdiger Köppe.

Petzell, M. 2015. Three Kagulu stories: Annotations, analysis, and word lists. Studia Orientalia Electronica 3. <http://ojs.tsv.fi/index.php/StOrE/article/view/48196> (27 April 2020).

Philippson, G. \& Nurse, D. 2000. Gweno, a little known Bantu language of Northern Tanzania. In Lugha za Tanzania/Languages of Tanzania: Studies Dedicated to the Memory of Prof. Clement Maganga, K. Kahigi, Y. Kihore \& M. Mous (eds), 233-284. Leiden: CNWS.

Pillinger, S. \& Galboran, L. 1999. A Rendille Dictionary Including a Grammatical Outline and an English-Rendille Index. Cologne: Rüdiger Köppe.

Roehl, K. 1911. Versuch einer systematischen Grammatik der Schambala sprache. [Abhandlungen des Hamburgischen Kolonialinstituts 2]. Hamburg: Friederichsen.

Rugemalira, J. 1993. Runyambo Verb Extension and Constraints on Predicate Structure. PhD dissertation, University of California at Berkeley.

Rugemalira, J. 2009. Cigogo: Kamusi ya Kigogo-Kiswahili-Kiingereza, Kiingereza-Kigogo, Kiswahili-Kigogo=Gogo-Swahili-English, English-Gogo, Swahili-Gogo Dictionary. Dar es Salaam: Mradi wa Lugha za Tanzania, Chuo Kikuu cha Dar es Salaam.

Sacleux, C. 1939. Dictionnaire Swahili - Français. Paris: Institut d'Ethnologie.

Schadeberg, T. C. 2000. Ekoti: The Maka or Swahili Language of Angoche. Cologne: Rüdiger Köppe.

Schrock, T. 2014. A Grammar of Ik (Icé-tód) Northeast Uganda's Last Thriving Kuliak Language. Utrecht: LOT.

Stegen, O. 2011. In Quest of a Vernacular Writing Style for the Rangi of Tanzania: Assumptions, Processes, Challenges. PhD dissertation, University of Edinburgh.

Stirnimann, H. 1983. Praktische Grammatik der Pangwa-Sprache (SW-Tansania). Freiburg, Schweiz: Universitätsverlag.

Ström, E-M. 2013. The Ndengeleko Language of Tanzania. PhD dissertation, Gothenburg Univ. $<$ https://gupea.ub.gu.se/handle/2077/32111> (27 April 2020).

Stroomer, H. 1995. A Grammar of Boraana Oromo (Kenya): Phonology, Morphology, Vocabularies. Cologne: Rüdiger Köppe.

TUKI. 1981. Kamusi ya Kiswahili sanifu. Dar es Salaam: OUP and Taasisi ya Uchunguzi wa Kiswahili (TUKI).

TUKI. 2001. Kamusi ya Kiswahili - Kiingereza. Dar es Salaam: Taasisi ya Uchunguzi wa Kiswahili (TUKI).

van der Wal, J. 2009. Word Order and Information Structure in Makhuwa-Enahara. Utrecht: LOT. Yoneda, N. 2006. Vocabulary of the Matengo Language. Tokyo: ILCAA.

Yukawa, Y. 1989. A Classified Vocabulary of the Nilamba Language. Tokyo: ILCAA. 


\section{Appendix. Table of transfer of 'until' in East Africa}

The table represents what I found in the languages of East Africa for which I had documentation. The second column gives the loan 'until' or a hyphen when there is no such loan. The next two columns indicate whether the complement can be place or time. This is mostly based on example sentence provided or sentences found in texts. Hence in many instances, information is lacking. I have not found a language that uses borrowed 'until' for only one of the two meanings. The next column indicates whether the preposition is attested with a clausal complement. This is only explicitly excluded for Makua. For many languages the evidence is inconclusive due to lack of information. The next column present alternatives to the preposition 'until' in the languages. The last but one column present the word for 'boundary' and whether is different (D), (3/4) indicates the noun class; sometimes the plural of the noun is given after |. The last column indicates the source for the data.

\begin{tabular}{|c|c|c|c|c|c|c|c|}
\hline Language & 'until' & Place & Time & _S & Other & 'boundary' & Source \\
\hline \multicolumn{8}{|c|}{ Non-Bantu languages } \\
\hline $\mathrm{Ik}$ & páka & $\mathrm{Y}$ & & $\mathrm{Y}$ & gone $\mathrm{P}$ & D: akánı' & $\begin{array}{l}\text { Schrock (2014: 250f, } \\
612)\end{array}$ \\
\hline Borana & haga & Y & & $\mathrm{Y}$ & & $\mathrm{D}$ & Stroomer (1995) \\
\hline Konso & $\begin{array}{l}\text { haka }+ \\
\text { GEN }^{*}\end{array}$ & $\mathrm{Y}$ & & & & $\mathrm{D}$ & $\begin{array}{l}\text { Orkaydo } \\
\text { (2013: 180f) }\end{array}$ \\
\hline Sandawe & pákâ & & $\mathrm{Y}$ & $\mathrm{Y}$ & $\mathrm{Y}$ & & Eaton (2010) \\
\hline Rendille & - & & & & $\begin{array}{l}\text { geeddi } C \\
\text { deeddi } C\end{array}$ & & $\begin{array}{l}\text { Pillinger and } \\
\text { Galboran (1999) }\end{array}$ \\
\hline Maasai & - & & & & o- & $\begin{array}{l}\text { ol-pólósié } \\
\text { (and other } \\
\text { words) }\end{array}$ & Payne (2008) \\
\hline Turkana & - & & & & tàni' & & $\begin{array}{l}\text { Dimmendaal } \\
(1983: 481)\end{array}$ \\
\hline Iraqw & - & & & & $\begin{array}{l}\text { ay, aydír } \\
+\mathrm{S} \text {, } \\
\text { afiqoomár } \\
<\text { mouth } \\
\text { period:of } \\
\mathrm{P}\end{array}$ & & $\begin{array}{l}\text { Mous (1993: 55, } \\
101)\end{array}$ \\
\hline
\end{tabular}

\begin{tabular}{|c|c|c|c|c|c|c|c|}
\hline Nyamwezi & mpáká & & & & & $\begin{array}{l}\text { D: loßí́mbí; } \\
\text { ma-lø- }\end{array}$ & $\begin{array}{l}\text { Maganga \& } \\
\text { Schadeberg (1992) }\end{array}$ \\
\hline Luganda & paka & & & & & $\begin{array}{l}\text { D: èsalè, } \\
\text { èmbobò, } \\
\text { ènkingì, }\end{array}$ & $\begin{array}{l}\text { Murphy (1972), } \\
\text { Mulira \& Ndawula } \\
(1952)\end{array}$ \\
\hline Ekoti & mpakha & Y & $\mathrm{Y}$ & $?$ & - & $\begin{array}{l}\text { D: mwiinano } \\
\text { | nyiinano } \\
(3 / 4)\end{array}$ & $\begin{array}{l}\text { Schadeberg } \\
(2000: 194)\end{array}$ \\
\hline
\end{tabular}




\begin{tabular}{|c|c|c|c|c|c|c|c|}
\hline Language & 'until' & Place & Time & _S & Other & 'boundary' & Source \\
\hline $\begin{array}{l}\text { Kivunjo } \\
\text { Chaga }\end{array}$ & mpaka & $?$ & $\mathrm{Y}$ & $?$ & $?$ & $\begin{array}{l}\text { D: ńdasâ | } \\
\text { mi-ńdasâ }\end{array}$ & Kagaya (2006) \\
\hline Nilamba & mpáka & & & & & mímbí & Yukawa (1989) \\
\hline Haya & mpáka & & & & & $\begin{array}{l}\text { olubîbi } \\
\text { | embîbi } \\
(11 / 10)\end{array}$ & Kaji (2000) \\
\hline Makonde & mpááka & & & & & $?$ & Leach (2010: 155) \\
\hline Makua & mhpaka & Y & $\mathrm{Y}$ & $\mathrm{N}$ & hata & $?$ & Van der Wal (2009) \\
\hline Ndengeleko & mpaka & & & & & $?$ & Ström (2013) \\
\hline Kagulu & mbaka & & $\mathrm{Y}$ & $\mathrm{Y}$ & & $?$ & $\begin{array}{l}\text { Petzell (2008, } \\
\text { 2015: 60) }\end{array}$ \\
\hline Bena & mpagha & Y & $?$ & $?$ & $?$ & $\begin{array}{l}\text { D: mbeto, } \\
\text { lugengetsi**}\end{array}$ & Morrison (2011) \\
\hline Shimaore & paka & & & & & $?$ & Alnet (2009) \\
\hline Mbugwe & mpaka & & & & & mopáka (3/4) & Mous (2004: 22) \\
\hline Rangi & mpaka & Y & $\mathrm{Y}$ & $\mathrm{Y}$ & forro Adv & $\begin{array}{l}\text { mo-haka } \\
(3 / 4)\end{array}$ & $\begin{array}{l}\text { Gibson } \\
(2013: 50,84) \\
\text { Dunham } \\
(2005: 83,141,192)\end{array}$ \\
\hline Mbugu & mpaka & $\mathrm{Y}$ & $\mathrm{Y}$ & & & mhpaka & Mous (2003) \\
\hline Ndamba & mbaka & $\mathrm{Y}$ & & Y & & mupaka & $\begin{array}{l}\text { Edelsten and } \\
\text { Lijongwa } \\
(2010: 131)\end{array}$ \\
\hline Zigula & mpaka & & & & & $\begin{array}{l}\text { mhaka } \\
\text { mi- }(3 / 4)\end{array}$ & Kisbey (1906) \\
\hline Shambala & mpaka & & & & shuti & $\begin{array}{l}\text { mhaka } \mid \\
\text { mi- }(3 / 4)\end{array}$ & Besha (1993) \\
\hline Gweno & mpaká & $\mathrm{Y}$ & $\mathrm{Y}$ & & & mw.aká $3 / 4$ & $\begin{array}{l}\text { Philippson \& Nurse } \\
(2000)\end{array}$ \\
\hline Pare & mháká & & & & $?$ & ṃhaka & Kagaya (1989) \\
\hline Gĩkũyũ & mpaka & $?$ & $?$ & $?$ & $?$ & mũhaka & Samuel Mdogo p.c. \\
\hline Kisii & mbaka & $?$ & $?$ & $?$ & $?$ & oroßago & Geofred Osoro p.c. \\
\hline Matengo & mpaka & $?$ & $?$ & $?$ & $?$ & ḿpaka & Yoneda (2006) \\
\hline Makwe & mpáaka & $?$ & $?$ & $?$ & $?$ & mpáaka & Devos (2008) \\
\hline Ilwana & mupaka & $?$ & $?$ & $?$ & $?$ & mupaka & Nurse (2000) \\
\hline Pogoro & mpaka & $?$ & $?$ & $?$ & $?$ & mpaka & Hendle (1907) \\
\hline
\end{tabular}

* The genitive consists of the vowel $a$ which merges with the final vowel of haka; hence it is an issue of analysis whether this genitive is present or not.

** Angelus Mnenuka p.c. Bayreuth colloquium. The first noun is most common. 
